\title{
Prevalence of Feline Viral Antibodies in Random-souce
}

\section{Laboratory Cats}

\author{
Hitoshi GOTO, Masao HORIMOTO※, Kiheiji SHIMIZU, Tikane HIRAGA*, \\ Toshihiro MATSUOKA*, Takeshi NAKANO**, Yasuo MOROHOSHI**, \\ Kazuyoshi MAEJIMA*** and Toru URANO***
}

\author{
Department of Veterinary Microbiology, Obihiro University of Agriculture and \\ Veterinary Medicine, Obihiro-shi, Hokkaido 080, *Department of Bacteriology, \\ Saitama Medical School, Moroyama, Iruma-gun, Saitama-ken 350-04, \\ **Department of Laboratory Animal Science, School of Medicine, \\ Kitasato University, 1 Kitasato, Sagamihara-shi, Kanagawa-ken \\ 228 and ***Laboratory Animal Center, Keio University \\ School of Medicine, Shinanomachi 35, Shinjuku, \\ Tokyo 160, Japan.
}

(Received for publication : January 6,1981 )

\begin{abstract}
Over a period of 1973 to 1979 , a serologic survey of virus infections was conducted on feline sera collected in four universities which located in different prefectures ; Obihiro, Saitama, Kanagawa and Tokyo. A significant hemagglutination-inhibition (HI) antibody titer of $1: 8$ or higher to feline panleukopenia virus (FPLV) was detected in $130(58 \%)$ of the 226 sera used. No remarkable difference in the HI antibody prevalence in cats to FPLV was recognized by years or localities. Of a total of 188 cats tested, $99(53 \%)$ presented positive serum neutralizing (SN) antibody titers to the No. 1 strain of feline calicivirus (FCV). Especially in Kanagawa, $17(77 \%)$ of the 22 cats had positive SN titers. However, only $42(22 \%)$ of the 188 sera showed positive SN titers to the Kyoritsu strain of FCV. Such lower positivity in the cats was observed with $13 \%$ in the SN test to human reovirus type 3 (Reo-3). The incidence of positive SN antibodies to feline rhinotracheitis virus (FRV) also remained in low values of 20 to $27 \%$ with the exception of high percentage of 86 in Tokyo. The dissemination of FPLV, FRV, FCV and Reo-3 was briefly discussed in relation with the age distribution of viral antibodies in cats.
\end{abstract}

\section{Introduction}

It is well known that a large number of feline virus diseases have a wide distribution among cat populations $[2,5]$. Especially, many of the cat colonies maintained for the use of various experiments are exposed to an invasion of the diseases. In this country, feline panleu- kopenia virus (FPLV) $[4,7,12,13]$, feline rhinotracheitis virus (FRV) $[3,9,14,16]$ and feline calicivirus (FCV) $[1,8,11,18]$ infections have frequently been recognized in laboratory or domestic cats. Reovirus infection of cats is widespread in U. S. A. and approximately $50 \%$ of the domestic cats in New York had antibodies to

※ Present Address : Nagoya Pharmacology Laboratory, Pheizer Taito Co. Ltd., 5-2 Taketoyo-cho, Chita-gun, Aichi-ken, 470-23. 
reovirus type 3 (Reo-3), although the importance of reovirus infection in cats is not well known as yet $[2,17]$. In Japan however, there are no reports on the prevalence of antibodies to this type of virus in cats. The purpose of this study was to elucidate the epidemiologic features from the antibody survey to these viruses in the serum samples collected from cats brought as a laboratory animal.

\section{Materials and Methods}

Viruses: Four feline viruses and one human reovirus were used in this study. The Obihiro strain of FPLV had been isolated from the spleen of diseased cat in 1974 [4]. The C-7301 strain of FRV had been isolated from domestic cat showing respiratory syndrome [14] and supplied by the courtesy of Dr. S. Konishi, Department of Veterinary Microbiology, Faculty of Agriculture, University of Tokyo, Tokyo. The No. 1 and Kyoritsu strains of FCV had been isolated from domestic cats with respiratory symptoms [8], and supplied by the courtesy of Dr. N. Fujie, the Central Laboratories, Kyoritsu Shoji Co., Ltd, Ibaragi. The human strain of Reo-3 was supplied by the courtesy of Dr. S. Urasawa, Department of Hygiene and Epidemiology, Sapporo Medical College, Sapporo.

Sera: The feline sera used were derived from cats brought in for an experimental purpose to the universities, which located in four prefectures of Japan ; Obihiro University (A) in Obihiro, Hokkaido, Saitama Medical School (B) in Saitama, Kitasato University (C) in Kanagawa and Keio University (D) in Tokyo. All the cats used were apparently healthy. The serum samples were collected during the period from 1973 to 1974 in A, and from 1978 to 1979 in B, C and D. The sera were taken immediately after the arrival of the cats to the laboratories, and stored at $-20^{\circ} \mathrm{C}$ until use. The age of cats was caught from their owner or, in part, surmised from the abrasion of teeth of animals in comparison with that of the cats of defined age. Specific goat immune sera against the strains of FPLV, FRV and FCV used in this study were supplied by the courtesy of Dr. J. H. Gillespie, Cornell University, Ithaca, New York as described elsewhere [7].

Cell cultures and virus assays: Primary kitten kidney (KK) cell cultures were prepared with trypsinization of the kidney of 3- to 4-week-old kitten and stored at $-80^{\circ} \mathrm{C}$ until more transfer. Details of $\mathrm{KK}$ cell culture method were described before [7]. Secondary or thirdly transferred $\mathrm{KK}$ cells were used for the preparation of stock virus or the virus assays of FPLV, FRV and FCV. RK-13 cell culture was used for Reo-3 assay. The RK-13 cells were propagated in Eagle's minimum essential medium (MEM, Nissui, Tokyo) containing $10 \%$ calf serum, 100 units of penicillin $\mathrm{G}$ potassium, $100 \mu \mathrm{g}$ of dihydrostreptomycin and $2.5 \mu \mathrm{g}$ of amphotericin $\mathrm{B}$ (Fungizone) per $\mathrm{ml}$ of medium. All the viruses were stored at $-80^{\circ} \mathrm{C}$ until use.

Serologic tests : Hemagglutination-inhibition (HI) test for FPLV was performed by the microtiter method using porcine erythrocytes according to the procedures described in the previous report [6]. Serum neutralizing (SN) tests for FRV, FCV and Reo-3 were also carried out by microtiter method. The test sera were mixed with equal volume of a phosphate buffered saline, $\mathrm{pH} 7.2$ and inactivated at $56^{\circ} \mathrm{C}$ for 30 minutes. To $0.025 \mathrm{ml}$ of twofold dilution of the treated serum in the abovementioned MEM ( $2 \%$ calf serum) in wells of microplate, an equal volume of the estimated $200 \mathrm{TCID}_{50}$ of the virus was added. The plate was incubated, after mixing, in a humidified $5 \% \mathrm{CO}_{2}$ incubator at $37^{\circ} \mathrm{C}$ for 1 hour. Then $0.05 \mathrm{ml}$ of MEM ( $10 \%$ calf serum) containing $2 \times 10^{5}$ $\mathrm{KK}$ or $\mathrm{RK}-13$ cells $/ \mathrm{ml}$ was added to each well, and the plate was reincubated at $37^{\circ} \mathrm{C}$ for 4 to 5 days. The SN antibody titer was expressed as reciprocal of the highest dilution of serum showing inhibition of 
Table 1. Cross HI and SN tests* among FPLV, FRV and FCV strains

\begin{tabular}{lcccc}
\hline Antisera & FPLV & FRV & \multicolumn{2}{c}{ FCV strains } \\
\cline { 4 - 5 } & (Obihiro) & $($ C-7301) & No. 1 & Kyoritsu \\
\hline FPLV & & & & \\
Obihiro & 160 & $0 * *$ & 0 & 0 \\
Cornell & 4096 & 0 & 0 & 0 \\
FRV & & & & \\
10 FVR & 0 & 160 & 0 & 0 \\
FCV & & & & \\
17 FRV & 0 & 0 & 20 & 10 \\
F 10 & 0 & 0 & 10 & 40 \\
F C & 0 & 0 & 40 & 10 \\
F 9 & 0 & 0 & 0 & 20 \\
K C D & 0 & 0 & 0 & 20 \\
F 17 & 0 & 0 & 0 & 10 \\
68 FIV & 0 & 0 & 0 & 160 \\
F 11, F S, & & & & \\
C 14, F 20, & 0 & 0 & 0 & 0 \\
F 5, 5PL & & & & \\
\hline
\end{tabular}

* HI test for FPLV strain.

SN tests for FRV and FCV strains.

** $0=\langle 1: 10$.

cytopathogenic effect when the titration of virus control using the medium instead of serum showed the $100 \mathrm{TCID}_{30}$ point.

\section{Results}

1. Comparison of antigenicities of the virus strains

Reciprocal or one-way $\mathrm{HI}$ and $\mathrm{SN}$ tests on FPLV, FRV and FCV strains used in this study were performed with the antiserum to Obihiro strain of FPLV [7] and the 15 feline virus antisera obtained from Cornell University (Table 1). The Obihiro strain reacted with only both antisera of homologous strain and Cornell strain of FPLV in the HI titers of $1: 160$ and 1:4096, respectively. The C-7301 strain of FRV also showed the SN antibody titer of $1: 160$ with the antiserum of 10 FVR strain of FRV alone. In the 2 strains of FCV, however, No. 1 strain reacted with the SN titers from $1: 10$ to $1: 40$ in 3 of the 13 antisera of FCV strains, and
Kyoritsu strain with the titers from $1: 10$ to $1: 160$ in the 7 sera. Each of the FCV strains had a different antigenicity of FCV. Then the both strains were used for the later experiment.

\section{FPLV antibody in cats}

The distribution of $\mathrm{HI}$ antibody titers to FPLV in feline sera collected as abovementioned were depicted in Fig. 1. Number of test sera in A, B, C and D were 39, 80,21 and 86, respectively. About a half of the sera collected in A, C and D $(46,48$ and $57 \%$ ) were shown to have a positive HI titer of $1: 8$ or higher to FPLV, and $66 \%$ of them in B had the positive titers. Of the 130 positive sera, $99(76 \%)$ showed a high titer of $1: 256$ or higher.

Table 2 gives the age distribution of $\mathrm{HI}$ antibody to FPLV in 39 feline sera collected in A (Obihiro) and 80 feline sera in B (Saitama). In Obihiro, more than a half of the cats aged 0 to 3 months (15/ 


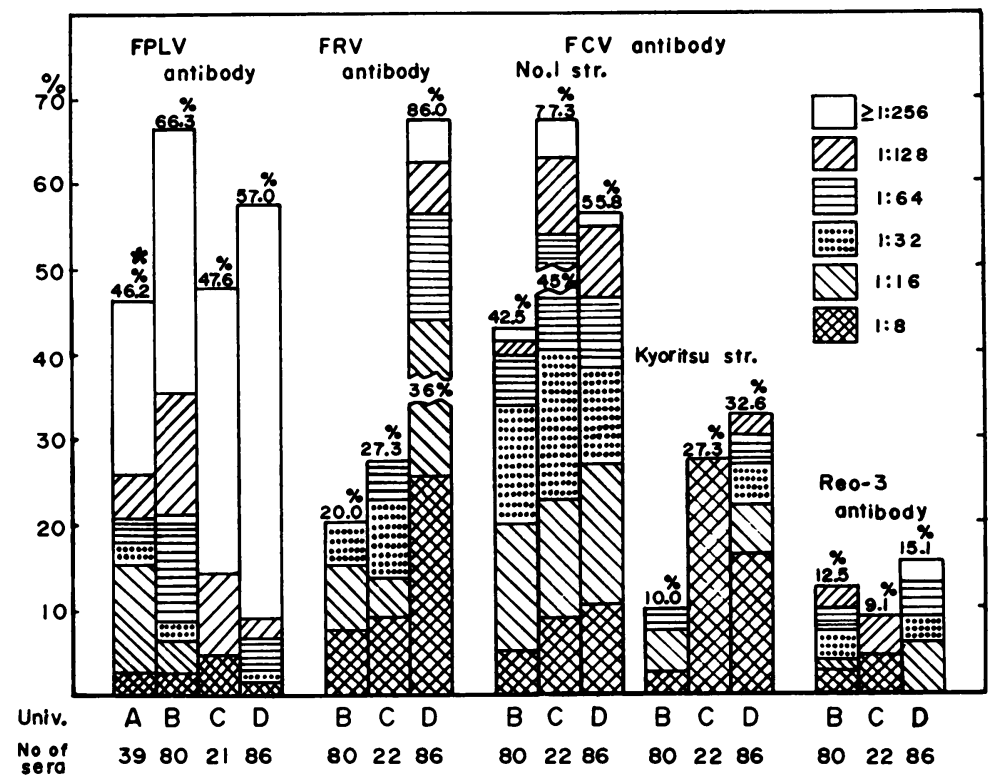

* Percentages of antibody titers of $1: 8$ or higher in $\mathrm{HI}$ and SN tests. A : Obihiro University (Obihiro) B : Saitama Medical School (Saitama) C : Kitasato University (Kanagawa) D : Keio University (Tokyo)

Fig. 1. Distribution of HI or SN antibody titers to FPLV, FRV, FCV and Reo-3 in cat sera collected in four universities in 1973-79 (HI antibody for FPLV, SN antibodies for other viruses.)

Table 2. Age distribution of FPLV antibody in cat sera collected in Obihiro (1973-74) and Saitama (1978-79)

\begin{tabular}{|c|c|c|c|c|c|c|c|c|c|c|c|}
\hline \multicolumn{2}{|c|}{ A (Obihiro) } & \multicolumn{4}{|c|}{$\begin{array}{l}\text { No. of sera with HI antibody } \\
\text { at indicated dilution }\end{array}$} & \multicolumn{2}{|c|}{ B (Saitama) } & \multicolumn{4}{|c|}{$\begin{array}{l}\text { No. of sera with } \mathrm{HI} \text { antibody } \\
\text { at indicated dilution }\end{array}$} \\
\hline Age & $\begin{array}{l}\text { No. of } \\
\text { sera }\end{array}$ & $\leq 4$ & $8-32$ & $64-256$ & $\geq 8 \quad(\%)$ & Age & $\begin{array}{l}\text { No. of } \\
\text { sera }\end{array}$ & $\leq 4$ & $8-32$ & $64-256$ & $\geq 8 \quad(\%)$ \\
\hline $0-1^{\mathrm{M}}$ & 18 & 9 & 4 & 5 & $9(50.0)$ & $1-3^{M}$ & 18 & 3 & 2 & 13 & $15(83.3)$ \\
\hline $2-3$ & 9 & 3 & 3 & 3 & $6(66.7)$ & $4-6$ & 2 & 2 & 0 & 0 & 0 \\
\hline $4-5$ & 2 & 2 & 0 & 0 & 0 & $7-1^{Y}$ & 11 & 7 & 0 & 4 & $4(36.4)$ \\
\hline $6-1^{Y}$ & 4 & 4 & 0 & 0 & 0 & $2-3$ & 24 & 7 & 3 & 14 & $17(70.8)$ \\
\hline $2-5$ & 6 & 3 & 0 & 3 & $3(50.0)$ & $4-7$ & 25 & 8 & 2 & 15 & $17(68.0)$ \\
\hline Total & 39 & 21 & 7 & 11 & $18(46.2)$ & Total & 80 & 27 & 7 & 46 & $53(66.3)$ \\
\hline
\end{tabular}

27 cases) and 2 years or older ( $3 / 6$ cases) presented positive titers to the virus, while the 6 cats aged 4 months to one year had a titer of $1: 4$ or less. The high antibody titers were observed on the sera from many of the young and adult cats. Such tendency was strong in the age distribution of $\mathrm{HI}$ antibody to FPLV in the sera collected in Saitama. That is, $15(83 \%)$ of the 18 cats aged 1 - to to 3 -month-old had positive titers to the virus, and then 39 $(70 \%)$ of the 49 cats 2 to 7 years old had 
Table 3. Age distribution of SN antibody to FRV in cat sera collected in Saitama (1978-79)

\begin{tabular}{lrrrrrrrrr}
\hline \multirow{2}{*}{ Age } & $\begin{array}{c}\text { No. of } \\
\text { sera }\end{array}$ & \multicolumn{6}{c}{$\begin{array}{c}\text { No. of sera with antibody at } \\
\text { indicated dilution }\end{array}$} & \multirow{2}{*}{$\geq 1: 8(\%)$} \\
\cline { 3 - 7 } & & $\leq 4$ & 8 & 16 & 32 & 64 & 128 & 256 & \\
\hline $1-3^{\mathrm{M}}$ & 18 & 13 & 0 & 3 & 2 & 0 & 0 & 0 & $5(27.8)$ \\
$4-6$ & 2 & 0 & 1 & 1 & 0 & 0 & 0 & 0 & $2(100)$ \\
$7-1^{\mathrm{Y}}$ & 11 & 10 & 0 & 1 & 0 & 0 & 0 & 0 & $1(9.1)$ \\
$2-3$ & 24 & 22 & 1 & 1 & 0 & 0 & 0 & 0 & $2(8.3)$ \\
$4-7$ & 25 & 19 & 4 & 0 & 2 & 0 & 0 & 0 & $6(24.0)$ \\
\hline Total & 80 & 64 & 6 & 6 & 4 & 0 & 0 & 0 & $16(20.0)$ \\
\hline
\end{tabular}

Table 4. Age distribution of SN antibodies to FCV strains in cat sera collected in Saitama (1978-79)

\begin{tabular}{|c|c|c|c|c|c|c|c|c|c|}
\hline \multirow{3}{*}{ Age } & \multirow{3}{*}{$\begin{array}{c}\text { No. of } \\
\text { sera }\end{array}$} & \multicolumn{8}{|c|}{ No. of sera with antibody at indicated dilution } \\
\hline & & \multicolumn{4}{|c|}{ No. 1 str. } & \multicolumn{4}{|c|}{ Kyoritsu str. } \\
\hline & & $\leq 4$ & $8-32$ & $64-256$ & $\geq 8 \quad(\%)$ & $\leq 4$ & $8-32$ & $64-256$ & $\geq 8 \quad(\%)$ \\
\hline $1-3^{\mathrm{M}}$ & 18 & 18 & 0 & 0 & 0 & 18 & 0 & 0 & 0 \\
\hline $4-6$ & 2 & 2 & 0 & 0 & 0 & 2 & 0 & 0 & 0 \\
\hline $7-1^{Y}$ & 11 & 6 & 3 & 2 & $5(45.5)$ & 11 & 0 & 0 & 0 \\
\hline $2-3$ & 24 & 8 & 14 & 2 & $16(66.7)$ & 20 & 3 & 1 & $4(16.7)$ \\
\hline $4-7$ & 25 & 12 & 10 & 3 & $13(52.0)$ & 21 & 3 & 1 & $4(16.0)$ \\
\hline Total & 80 & 46 & 27 & 7 & $34(42.5)$ & 72 & 6 & 2 & $8(10.0)$ \\
\hline
\end{tabular}

the positive titers. On the contrary, 2 cats 4 to 6 months old had no antibody titer, although only $4(36 \%)$ of the 11 cats aged 7 months to one year old showed the positive titers.

\section{FRV antibody in cats}

SN antibody titers to FRV were examined on the feline sera collected in B, $\mathrm{C}$ and $\mathrm{D}$ (Fig. 1). Of the 80 sera in $\mathrm{B}, 16$ $(20 \%)$ showed a positive SN titer of $1: 8$ or higher to the virus and $6(27 \%)$ of the 22 sera in $\mathrm{C}$ had also the positive titers. On the contrary, majority of the cats (74/ 86 cases, $86 \%$ ) in $\mathrm{D}$ presented positive titers to FRV. There were marked differences in FRV antibody distribution in cats between $D$ and $B$ or $C$.

Table 3 represents the age distribution of SN antibody to FRV in 80 feline sera collected in B. Although the positive antibody titers were observed extending over all the 5 age groups of cats, there were no special tendency by the age of cats.

\section{FCV antibody in cats}

The titration of SN antibody to FCV was performed with the two strains possessing different antigenicity. Against the No. 1 strain of FCV, $34(43 \%)$ of the 80 sera in B, $17(77 \%)$ of the 22 sera in C, and $48(56 \%)$ of the 86 sera in $D$ reacted respectively, and they had SN antibody titers in a wide range from $1: 8$ to $1: 256$. On the contrary, a small number of sera, such as $8(10 \%), 6(27 \%)$ and $28(33 \%)$ of the same samples, presented positive titers to the Kyoritsu strain of FCV. These titers distributed in a narrow range from $1: 8$ to $1: 32$ in $B$ and $C$. Then the antibody distribution in cats is considerably 
Table 5. Age distribution of SN antibody to Reo-3 in cat sera collected in Saitama (1978-79)

\begin{tabular}{|c|c|c|c|c|c|c|c|c|c|}
\hline \multirow[t]{2}{*}{ Age } & \multirow{2}{*}{$\begin{array}{c}\text { No. of } \\
\text { sera }\end{array}$} & \multicolumn{7}{|c|}{$\begin{array}{l}\text { No. of sera with antibody at } \\
\text { indicated dilution }\end{array}$} & \multirow{2}{*}{$\geq 1: 8(\%)$} \\
\hline & & $\leq 4$ & 8 & 16 & 32 & 64 & 128 & 256 & \\
\hline $1-3^{M}$ & 18 & 18 & 0 & 0 & 0 & 0 & 0 & 0 & 0 \\
\hline $4-6$ & 2 & 2 & 0 & 0 & 0 & 0 & 0 & 0 & 0 \\
\hline $7-1^{Y}$ & 11 & 10 & 1 & 0 & 0 & 0 & 0 & 0 & $1(9.1)$ \\
\hline $2-3$ & 24 & 20 & 0 & 0 & 1 & 2 & 1 & 0 & $4(16.7)$ \\
\hline $4-7$ & 25 & 20 & 1 & 1 & 2 & 0 & 1 & 0 & $5(20.0)$ \\
\hline Total & 80 & 70 & 2 & 1 & 3 & 2 & 2 & 2 & $10(12.5)$ \\
\hline
\end{tabular}

different between $\mathrm{C}$ and $\mathrm{B}$ or $\mathrm{D}$ to the No. 1 strain, and between $B$ and $C$ or $D$ to the Kyoritsu strain.

Table 4 indicates the age distribution of SN antibody to FCV in 80 feline sera collected in B. No antibodies against the No. 1 strain were detected in the sera of cats under 6 months old, and also against the Kyoritsu strain, in all the sera of the cats less than one year old. However, the cats over 7 months of age had a SN antibody titer of $1: 8$ or higher to the No. 1 strain, and the cats over 2 years old reacted positive to the Kyoritsu strain.

\section{Reo-3 antibody in cats}

The human strain of Reo-3 was used for the detection of antibody in sera of cats, because it was impossible to obtain a feline strain of reovirus in the present study. As shown in Fig. 1, $10(13 \%)$ of the 80 feline sera collected in B, $2(9 \%)$ of the 22 sera in $\mathrm{C}$, and $13(15 \%)$ of the 86 sera in $\mathrm{D}$, respectively presented positive SN antibody titer of $1: 8$ or higher to Reo-3. These percentages were extremely low as compared to those of the antibody prevalence in cats to all the feline viruses described above.

Table 5 lists the age distribution of SN antibody to Reo-3 in the 80 sera collected in B. No antibody titers to the virus were found out on all the sera of cats under one year old with the exception of one cat of 1-year-old showing the titer of $1: 8$. In the groups of the cats over 2 years old, only 9 of the 49 cats had the positive titers to Reo-3.

\section{Discussion}

The results of this serologic survey indicate that FPLV and FCV (No. 1) of the 5 viruses tested showed very wide prevalence among the cat populations. Over a period of $1973-74$ or $1978-79$, a significant $\mathrm{HI}$ antibody titer of $1: 8$ or higher to FPLV was detected in 46 to $66 \%$ of the feline sera collected each in four laboratories which were located in different prefectures. These values agree well with the $54 \%$ which was reported by the authors (Goto and Shimizu) on the healthy cat sera collected during the years 1970-71 in Obihiro [7]. These findings show that the infection of FPLV in cats is widely spread with almost the same rate of incidence throughout this country, at least Hokkaido and Kanto districts of Japan, and that no considerable differences in the dissemination of virus were observed by the years of serologic surveys. In the age distribution of FPLV antibodies among the cats, there are highly suggestive facts on the real prevalence of virus. That is, many of the young cats (1- to 3-monthold) had the high HI titers to FPLV which seemed to be transferred passively from their dams. These titers, however, decreased to low or undetectable level from the 4 th to the 12 th month after birth. 
Therefore, young cats became susceptible to FPLV infection and may be infected with virus when they grew up one to 2 years of age. As a result of the infection, the cats of 2 years or older of age had the high antibody titers to FPLV. For immunization of cats, it had been recommended in U. S. A. [2] that a vaccination program with the inactivated FPLV should begin on the 9 to 10 weeks of age followed by the 2nd injection 2 weeks later. For maximum protection, moreover, it is recommended that the $3 \mathrm{rd}$ vaccination should be given when the cat is 16 weeks old. This method may be useful as means of immunizing cats also in this country, since none of the cats 4 to 6 months old presented positive $\mathrm{HI}$ titers to FPLV in the present study.

As for the No. 1 strain of FCV, of a total of 188 cats tested, $99(53 \%)$ presented a positive $\mathrm{SN}$ antibody titer of $1: 8$ or higher to the virus. Especially in Kanagawa (C), $17(77 \%)$ of the 22 cats had the positive titers. On the contrary, only $42(22 \%)$ of the 188 feline sera showed the positive titers to the Kyoritsu strain of FCV. The results indicate that there were marked differences in the antibody prevalence in the cats between the No. 1 and Kyoritsu strains of FCV. Further studies on this problem are necessary in the use of more strains, although FCV strains had been shown essentially as a single serotype, with a few strains of serologic variants [15], or with the exception of one-way cross-reacted strains [10].

In the antibody survey of the cats to FRV and Reo-3, the incidence of positive antibodies remaind low values ranging from 9 to $27 \%$ in both viruses, except for the incidence of FRV was so high as $86 \%$ in the 86 feline sera which were derived from Tokyo (D). Although the serum samples were collected over a period from March to October, 1979, there are no actual reasons to explain such highest percentage. The problem of the traders of cat supply, however, was not under consideration in the present study.

In the age distribution of $\mathrm{SN}$ antibodies to FRV, FCV and Reo-3, FRV antibody was not characterized by the age of cats although in FCV and Reo-3 there were considerable correlations between the antibody response and the age of cats. The incidence of positive to each strain of FCV and Reo-3 increased with the age of cats. This finding tended to be remarkable in the cats of 2-year-old or over. The reslut suggests that the FCV and Reo-3 strains used, except the No. 1 strain of FCV, do not still spread among the cat populations in this country.

(This work was supported in part by a grantin-aid No. 339022 for the research from Ministry of Education, Science and Culture of Japan)

\section{References}

[1] Akimoto, T., Tada, N., Hase, T., Hara, M., Tabuchi, K., and Imai, N. (1973). Studies on feline picornavirus infection. J. Vet. Med. (Zyui-TikusanShinpo), 582, 26-33 (in Japanese).

[2] American Veterinary Medical Association. (1971). Report of the panel on the colloquium on selected feline infectious diseases. J. Am. Vet. Med. Assoc., 158, 835-843.

[3] Doi, K., Kojima, A., Inami, Y., Yasoshima, A., and Okawa, H. (1975). Feline viral rhinotracheitis in Japan-Isolation of herpes type virus and pathologic picture. Jpn. J. Vet. Sci., 37, 281-292 (in Japanese with English summary).

[4] Doi, K., Okawa, H., Sakuma, S., and Okaniwa, A. (1975). Histopathology of feline panleukopenia in domestic cats. Nat. Inst. Anim. Health Q. (Jpn)., 15, $76-85$.

[5] Gillespie, J. H., and Scott, F. W. (1973). Feline viral infections. Adv. Vet. Sci. Comp. Med., 17, 164200.

[6] Goto, H. (1975). Feline panleukopenia in Japan. II. Hemagglutinability of the isolated virus. Jpn. J. Vet. Sci., 37, 431-437.

[7] Goto, H., Yachida, S., Shirahata, T., and Shimizu, K. (1974). Feline panleukopenia in Japan. I. Isolation and characterization of the virus. Jpn. J. Vet. Sci., 36, 203-211.

[8] Hiraga, T., Arai, S., and Fujie, N. (1973). On the feline calicivirus infection-like disease. J. Vet. Med. (Zyui-Tikusan-Shinpo), 603, 15-18 (in Japanese).

[9] Itakura, C., Gotoh, T., Hashimoto, A., Suganuma, Y., Okada, K., and Fujimoto Y. (1972). Pathological observations of feline respiratory disease caused by herpes type virus. Jpn. J. Vet. Sci., 34, Suppl., 112 (Summary in Japanese). 
[10] Kalunda, M., Lee, K. M., Holmes, D. F., and Gillespie, J. H. (1976). Serological classification of feline caliciviruses by plaque-reduction neutralization and immunodiffusion. Am. J. Vet. Res., 36, 353356.

[11] Kamizono, M., Konishi, S., Ogata, M., and Kobori, S. (1968). Studies on cytopathogenic viruses isolated from cats with respiratory infections. I. Jpn. J. Vet. Sci., 30, 197-206.

[12] Konishi, S., Mochizuki, M., and Ogata, M. (1975). Studies on feline panleukopenia. I. Isolation and properties of virus strains. Jpn. J. Vet. Sci., 37, 439-449.

[13] Konishi, S., Ohta, T., Ogata, M., Sato, A., Ishida, K., and Yamamoto, S. (1964). Studies on feline infectious enteritis I. Transmission of the virus. Jpn. J. Vet. Sci., 26, Suppl., 355 (Summary in Japanese).

[14] Mochizuki, M., Konishi, S., and Ogata, M. (1977).
Studies on cytopathogenic viruses from cats with respiratory infections. III. Isolation and certain properties of feline herpesviruses. Jpn. J. Vet. Sci., 39, 27-37.

[15] Povey, R. C. (1974). Serological relationships among feline caliciviruses. Infect. Immun., 10, 1307-1314.

[16] Sasaki, N., Nakai, M., Iwamoto, I., Ueba, O., Kokita, T., and Suma, I. (1968). Occurrence of feline viral rhinotracheitis-like disease. Jpn. J. Vet. Sci., 30 Suppl., 120 (Summary in Japanese).

[17] Scott, F. W., Kahn, D. E., and Gillespie, J. H. (1970). Feline viruses: Isolation, characterization, and pathogenicity of a feline reovirus. Am. J. Vet. Res., 31, 11-20.

[18] Takahashi, E., Konishi S., and Ogata, M. (1971). Studies on cytopathogenic viruses isolated from cats with respiratory infections. II. Characterization of feline picornaviruses. Jpn. J. Vet. Sci., 33, 81-87.

\title{
実験用ネコにおける二, 三のネコウイルスに対する血清抗体調査
}

後藤仁・堀本政夫 ·清水亀平次 - 平賀干兼* ·松岡俊弘* 中野健司**. 諸星康雄** ·前島一淑*** . 浦野徹***

\author{
帯広畜産大学家蓄微生物学教室 \\ $*$ 埼玉医科大学細菌学教室 \\ ** 北里大学医学部実験動物系 \\ *** 慶応義轵大学医学部実験動物センター
}

1973－79年間に, 帯広, 埼玉, 神奈川および東京に位 置する 4 大学に実験研究用として搬入された捕獲ネコに ついて二, 三のウイルス性感染病の伝播様相を血清学的 に検討した。汎白血球減少症ウイルス (FPLV) に対し て1：8以上の HI 抗体価を保有したネコは226例中 130 例 (58\%) に認められ, 大学別の保有率も46 66\%で, 本ウイルスはわが国のネコの間に, 調査時期と場所に関 係なく広く伝播していた。また FPLV 抗体の年令別分 布では, 生後 3 力月未満の若令期と $2 \sim 7$ 才時に保有率 と抗体レベルがともに高く，逆に 4 力月令から 1 才時の それらは著しく低い值を示した。鼻気管炎ウイルス （FRV）1株とカリシウイルス（FCV）の抗原性を異に する 2 株に対する中和抗体では, 供試した 3 大学由来血
清において，それぞれのウイルス株に対する各大学の抗 体保有率に大きな差がみられ，とくに FRV に対し $86 \%$ (74/86 例, 東京) ならびに FCV の No. 1 株に対し77 $\%(17 / 22$ 例, 神奈川) の高率を示すネコ集団がみられ た。レオウイルス 3 型 (Reo-3) に対する中和抗体では, 可検血清 188例中 25例（13\%）が陽性を示し，大学別の 抗体保有率でも9 15\%と低率であった。また FCV(共 立株）とReo-3 抗体の年令別分布では 1 才令未満で抗 体陽性を示すものは著しく少なく，それ以降年令の進む につれて抗体保有率が上昇するなど，これらのウィルス がまだネコの間に広く伝播していないことを示唆する成 績がえられた。 